in activity during greening. It appears that the development of chloroplast and peroxisomal enzyme activities may respond to illumination in the same way.

The development of the activities of all of these enzymes of glycollate metabolism was unaffected by D-threo-chloramphenicol, in contrast with essentially complete and specific inhibition of the development of ribulose diphosphate carboxylase and phosphoribulokinase activities by this compound (Ireland \& Bradbeer, 1971). This implies that the synthesis of these enzymes occurs on cytoplasmic ribosomes and not on chloroplast ribosomes. Codd \& Merrett (1970) reported that D-threo-chloramphenicol inhibited the development of phosphoglycollate phosphatase in greening Euglena, but omitted the essential control experiment with one of the other chloramphenicol isomers.

We thank the Science Research Council for a grant.

Bradbeer, J. W. (1969). New Phytol. 68, 233.

Bradbeer, J. W. (1970). New Phytol. 69, 635.

Codd, G. A. \& Merrett, M. J. (1970). Planta, 95, 127.

Ireland, H. M. M. \& Bradbeer, J. W. (1971). Planta, 96, 254.

Thompson, C. M. \& Whittingham, C. P. (1967). Biochim. biophys. Acta, 143, 642.

Tolbert, N. E., Yamazaki, R. K. \& Oeser, A. (1970). J. biol Chem. 245, 5129.

\section{The Chemical Composition of Dogfish Myelin}

By H. C. Agrawal, N. L. Banik, A. H. Bone, M. L. Cuzner, A. N. Davison and R. F. Mrtchell. (Department of Biochemistry, Charing Cross Hospital Medical School, Chandos Place, London WC2N 4HH, U.K.)

Purified myelin of most vertebrates hitherto investigated is characterized by the presence of basic encephalitogenic protein, by the marker enzyme $2^{\prime}: 3^{\prime}$-cyclic nucleotide $3^{\prime}$-phosphohydrolase and by a relatively high concentration of glycolipid.

Dogfish (Scyliorhinus caniculus) myelin prepared and purified by the method of Norton (1971) gave electron micrographs closely resembling those of myelin from other species with a clearly defined intraperiod line. Gel electrophoresis in phenolacetic acid-water (Takayama, MacLennan, Tzagoloff \& Stoner, 1966) gave a double band of basic protein resembling those of myelin from the mouse and the rat, with a mobility slightly less than that of cytochrome $c$. The basic protein has also been examined in dilute-acid (pH3) extracts of white matter, a procedure giving similar basicprotein patterns to extracts of isolated myelin (Martenson, Deibler \& Kies, 1969). This preparation from dogfish on electrophoresis in $1 \mathrm{M}$-acetic acid (Martenson, Deibler \& Kies, 1970) gave one main band and also two minor bands that migrated ahead of those seen with preparations from all other vertebrates examined, with mobilities similar to that of lysozyme. Electrophoresis at pH 10.6 (Martenson et al. 1969) gave three diffuse bands, a pattern again unlike that obtained with preparations from any other species. Not only was the protein electrophoretically different, but it failed to produce experimental allergic encephalomyelitis when injected with Freund's complete adjuvant into guinea pigs.

Also unlike that of other vertebrates, dogfish myelin was found to have no detectable phosphohydrolase activity. Although Cuzner, Davison \& Gregson (1965) found similarity in the lipid patterns of vertebrate myelin preparations, further analysis has shown that the concentrations of sulphatide and cerebroside in dogfish myelin are equal whereas in other species the cerebroside concentration is 3-4 times that of sulphatide. The enhanced myelin sulphatide concentration in the dogfish is accompanied by a relatively low brain sulphatase activity. Our findings suggest a greater species variation in myelin composition than had previously been suspected. Further, it now appears that encephalitogenic activity is not an essential property of the basic protein thought to be localized in the intraperiod line of the myelin sheath (Dickenson, Jones, Aparicio \& Lumsden, 1970; Adams, Bayliss, Hallpike \& Turner, 1971).

We are grateful to Dr J. R. Sargent for supplying us with dogfish used in this study.

Adams, C. W. M., Bayliss, O. B., Hallpike, J. F. \& Turner, D. R. (1971). J. Neurochem. 18, 389.

Cuzner, M. L., Davison, A. N. \& Gregson, N. A. (1965). J . Neurochem. 12, 469.

Dickenson, J. P., Jones, K. M., Aparicio, S. R. \& Lumsden, C. E. (1970). Nature, Lond., 227, 1133.

Martenson, R. E., Deibler, G. E. \& Kies, M. W. (1969). J. biol. Chem. 244, 4261 .

Martenson, R. E., Deibler, G. E. \& Kies, M. W. (1970). Biochim. biophys. Acta, 200, 353.

Norton, W. T. (1971). Adv. exp. Med. \& Biol.13, 329.

Takayama, K., MacLennan, D. H., Tzagoloff, A. \& Stoner, C. D. (1966). Archs Biochem. Biophys. 114, 223.

Relationship between Ribonucleic Acid Synthesis and the Mechanism of Enzyme Induction in Mammalian Liver

By M. K. Agarwal. (Institut Pasteur, 28 rue du Docteur Roux, Paris XVe, France).

The early, precise and orderly manner in which biogenesis of selected proteins is amplified after a corticosteroid hormone administration affords an 
opportunity to understand the mechanism underlying the expression of genetic information in mammalian liver. This induction of enzymes by corticoids is currently believed to be secondary to the hormonal stimulation of hepatic RNA synthesis (see brief review by Agarwal, Hanoune, Yu, Weinstein \& Feigelson, 1969).

To determine whether induction of enzymes can still be selectively modified when hormonally increased RNA synthesis remains unimpaired, a mixture of $\left[5-{ }^{3} \mathrm{H}\right]$ orotate and $\left[\mathrm{U}-{ }^{14} \mathrm{C}\right]$ glycine was employed to evaluate hepatic RNA and protein synthesis in relation to specific enzyme modifications after endotoxin administration in adrenalectomized rats. In the first few hours endotoxin modified neither the endogenous nor the cortisonestimulated rate of precursor incorporation into RNA and protein. The native activity and the hormonal induction of tryptophan oxygenase, but not of tyrosine transaminase, are repressed at these and earlier time-points by endotoxin.

On the other hand, in the first few hours of carbon tetrachloride administration in mice, a normal activity of tryptophan oxygenase and some induction of tyrosine transaminase were obtained; subsequently both these activities were adversely affected. Incorporation of $\left[5 \cdot{ }^{3} \mathrm{H}\right]$ orotate, however, was $30 \%$ below normal within $3 \mathrm{~h}$ of carbon tetra. chloride administration and remained low 18-20 h later. Cortisone did not augment the subnormal rate of RNA synthesis in carbon tetrachlorideinjected mice, but fully induced both the enzymes in the first few hours of carbon tetrachloride poisoning; enzyme induction was subsequently eliminated.

These studies established unequivocally that the general, non-specific, increase in total RNA synthesis effected by cortisone does not seem to be necessary for the induction of specific enzymes by the hormone. So it appears that biogenesis of specific proteins does not proceed via a mass-action or 'pushing' mechanism due to a grossly increased content of total RNA. All the evidence suggests that some specific events of transcription and/or translation may be required for the inductive process in intact mammalian liver.

Finally, cortisone, endotoxin and carbon tetrachloride all rapidly and markedly alter Kupffer-cell function in liver (Snyder, Agarwal \& Berry, 1967). So the reticuloendothelial system may be involved in the expression of genetic information in mam. malian liver in an as yet undefined manner (Agarwal, Hoffman \& Rosen, 1969).

Agarwal, M. K., Hanoune, J., Yu, F. L., Weinstein, I. B. \& Feigelson, P. (1969). Biochemistry, Easton, 8, 4806.

Agarwal, M. K., Hoffman, W. W. \& Rosen, F. (1969). Biochim. biophys. Acta, 177, 250.
Snyder, I. S., Agarwal, M. K. \& Berry, L. J. (1967). J. Bact. 94, 1817.

Oestradiol, Adenosine 3':5' - Cyclic Monophosphate and Nucleolar Ribonucleic Acid Polymerase in Calf Endometrium

By M. Mousseron-Canet, M. Arnadd, Y. Beziat, J. L. Borgna and J. C. GuIlleux. (Laboratoire de Chimie Photobioorganique du Centre Nationale de Recherche Scientifique, Ecole Nationale Supérieure de Chimie, Montpellier, France)

Two types of enzyme showing RNA polymerase activity have been isolated simultaneously from calf uteri. One of them, 'soluble RNA polymerase', is not bound to the gene; it is inhibited by $\alpha$-amanitine and is not stimulated by the cytoplasmic $5 \mathrm{~S}$ receptor-oestradiol complex.

The other, 'nucleolar RNA polymerase', is recovered from nucleoli that have been obtained by sonication of the isolated nuclei. This enzyme is stimulated by the cytoplasmic $5 \mathrm{~S}$ receptoroestradiol complex.

When the endometrium is incubated in $\left[{ }^{3} \mathrm{H}\right]$ oestradiol, the radioactivity of the nuclei is concentrated in the nucleoli. The RNA polymerase isolated from these nucleoli is also radioactive, and its enzyme activity is greatly enhanced compared with enzyme prepared from tissue that has not been treated with the hormone. A radioactive protein with a sedimentation coefficient of approx. $5 \mathrm{~S}$ can be liberated by treatment with potassium chloride from the nucleoli that have been labelled with $\left[{ }^{3} \mathrm{H}\right]$ oestradiol.

These results place one of the effects of the hormone in the nucleolus. The $5 \mathrm{~S}$ receptoroestradiol complex could be a factor that stimulates nucleolar RNA polymerase (Arnaud, Beziat, Guilleux \& Mousseron-Canet, 1971).

The effect of the hormone on the sedimentation profile of nucleolar RNA has been investigated.

A relationship between oestradiol, cyclic AMP (adenosine $3^{\prime}: 5^{\prime}$-cyclic monophosphate) and nucleolar RNA polymerase has been demonstrated.

Arnaud, M., Beziat, Y., Guilleux, J. C. \& Mousseron-Canet, M. (1971). C. r. hebd. Séanc. Acad. Sci., Paris, 272, 635.

\section{A Ghromatin-Bound Receptor-Oestradiol Gomplex in Ghicken Oviduct and its Effect on Ghromatin-Bound Deoxyribonucleic Acid- Dependent Ribonucleic Acid Polymerase Activity}

By R. F. Cox and N. H. CareY. (Searle Research Laboratories, High Wycombe, Bucks., U.K.)

Our work has been concerned with evaluating the technique of incubation of chicken oviduct tissue with labelled oestradiol in vitro as a model 